\title{
Split Applications of Copper Fungicides Improve Control of Melanose on Grapefruit in Florida
}

\author{
L. W. Timmer, Professor of Plant Pathology; S. E. Zitko, Senior Biologist; and L. G. Albrigo, Professor of Horti- \\ culture, University of Florida, Citrus Research and Education Center, Lake Alfred 33850
}

\begin{abstract}
Timmer, L. W., Zitko, S. E., and Albrigo, L. G. 1998. Split applications of copper fungicides improve control of melanose on grapefruit in Florida. Plant Dis. 82:983-986.

Citrus melanose, caused by Diaporthe citri, is a major disease of fresh market grapefruit which is controlled primarily by preventive applications of copper fungicides. The goal of this research was to improve melanose control without increasing the total amount of metallic copper utilized. Disease control was assessed in field experiments for 3 years using one, two, three, or four applications of copper fungicides in which the same total amount of metallic copper was applied per season in each program. Melanose was severe in 1995 and 1997, and the four-application schedule provided better control than the one-, two-, or three-application programs. In 1996, disease pressure was low and all programs and fungicides provided equally effective control. Analysis of copper residues on the fruit indicated that loss of protection was attributable more to increase in fruit surface area when fruit were growing rapidly than to removal of copper by weathering. On larger, slower-growing fruit, loss of copper residues was apparently due to both factors. Economic evaluation of improved packouts of fresh market fruit and additional application costs indicated that net returns would be increased by $\$ 650$ to $\$ 1,250$ per hectare during years in which melanose was severe when the four-spray program was compared to a single spray.
\end{abstract}

Copper fungicides are the primary products used for chemical control of foliar fungal diseases of citrus $(7,10,11)$. These materials are recommended for control of melanose caused by Diaporthe citri F.A. Wolf, greasy spot caused by Mycosphaerella citri Whiteside, citrus scab caused by Elsinoe fawcettii Bitancourt \& Jenk., and Alternaria brown spot caused by Alternaria alternata (Fr.:Fr.) Keissl. pathotype citri Solel. They are the only fungicides recommended for management of melanose and Alternaria brown spot (7). Large amounts of metallic copper are applied to citrus groves in Florida every year, especially in groves where the fruit is destined for the fresh market.

Although copper fungicides are inexpensive and highly effective for control of melanose and other citrus diseases, there are problems associated with their use. Application over many years has resulted in the accumulation of copper in soils, with some old orchard sites containing up to $370 \mathrm{~kg} / \mathrm{ha}$ of metallic copper $(3,4)$. Such high levels of copper are toxic to citrus

Corresponding author: L. W. Timmer

E-mail: 1wt@icon.lal.ufl.edu

Florida Agricultural Experiment Station Journal Series no. R-01685.

Accepted for publication 18 May 1998.

Publication no. D-1998-0618-02R

(C) 1998 The American Phytopathological Society roots and interfere with the uptake of iron and other nutrients, especially in acid soils. Liming of soils to $\mathrm{pH} 6.5$ reduces the availability of cupric ion and ameliorates the phytotoxic effects of copper $(3,4)$. Copper is not readily leached and is usually removed from soils by surface run-off when bound to organic matter and debris (3).

In addition to copper accumulation in soil, copper fungicides can cause spray injury to leaves and fruit and also darken existing blemishes caused by wind scar or other injuries $(5,9)$. These phytotoxic effects occur most commonly when copper is applied in complex tank mixes with other pesticides, petroleum spray oils, or nutritional materials, and when applications are made at high temperatures $(1,9)$. Copper damage can usually be reduced by applying lower rates of fungicide in larger volumes of water (2).

In recent years, demand for high-quality, blemish-free grapefruit has increased, especially in the export market. In an attempt to achieve better melanose control, growers have applied copper fungicides more frequently without greatly reducing the rate of application. This has led to increased problems with phytotoxicity, especially where spray volumes have been reduced concomitantly (2).

A previous study (10) indicated that the amounts of metallic copper applied can be reduced by using newer, more effective products which contain less metallic copper. In the present study, we sought to as- certain whether melanose control could be improved by increasing the frequency of application without increasing the total amount of metallic copper applied per hectare per year. Copper residues on fruit were determined for some applications to ascertain whether loss of control was due to weathering of copper deposits or due to dilution of deposits as the surface area of the growing fruit increases.

\section{MATERIALS AND METHODS}

Fungicide application and evaluation of disease severity. The effect of the number of copper fungicide applications on control of melanose on grapefruit (Citrus paradisi Macf.) was evaluated from 1995 to 1997. In all cases, the same amount of metallic copper was applied per season in one, two, three, or four applications and compared to a non-sprayed control. Tests were conducted in a mature Marsh grapefruit grove on rough lemon (C. jambhiri Lush) rootstock planted on a 5.1 by $9.0 \mathrm{~m}$ spacing near Haines City, Florida. Each treatment was replicated five times on three-tree plots arranged in a randomized complete block design. Guard trees were located between plots within rows and one guard row was located between treated rows. All applications were made with a commercial airblast sprayer using 2,400 liters/ha in 1995 and 1996 and 1,200 liter/ha in 1997.

In 1995, Kocide DF (copper hydroxide, 40\% metallic copper; Griffin Chemical Co., Valdosta, GA) and Champ Formula II Flowable (copper hydroxide, $36 \%$ metallic copper wt/vol; Agtrol Chemical Co., Houston, TX) were evaluated. Treatments were (i) one application of Kocide DF at $22.7 \mathrm{~kg} / \mathrm{ha}$ (9.1 kg metallic $\mathrm{Cu})$ on 10 May; (ii) two applications at $11.4 \mathrm{~kg} / \mathrm{ha}$ on 1 May and 31 May; (iii) three applications at $7.6 \mathrm{~kg} / \mathrm{ha}$ on 20 April, 10 May, and 31 May; (iv) four applications at $5.7 \mathrm{~kg} / \mathrm{ha}$ on 12 April, 1 May, 22 May, and 9 June; and (v) an unsprayed control. The Champ Formula II treatment series was applied on the same dates using a total of 12.6 liters/ha $(4.5 \mathrm{~kg} / \mathrm{ha}$ of metallic copper as recommended by the manufacturer) for the entire season in one, two, three, or four sprays. The total amount of metallic copper applied in the Champ treatments was onehalf of that applied in the Kocide treatments.

In 1996, the test was repeated as above except that Kocide 2000 (copper hydrox- 
ide, $35 \%$ metallic $\mathrm{Cu}$ ) was used in place of Kocide DF. The rate of product used was increased to $26.0 \mathrm{~kg} / \mathrm{ha}$ per season to maintain the metallic copper applied at the same level as Kocide DF in the previous year, $9.1 \mathrm{~kg} / \mathrm{ha}$. Champ Formula II Flowable was applied at the same rate as in 1995. Application dates were: one spray, 10 May; two sprays, 1 May and 31 May; three sprays, 22 April, 10 May, and 31 May; and four sprays, 11 April, 1 May, 22 May, and 7 June.

In 1997, only Kocide 2000 was evaluated and the rate per season was reduced to $11.4 \mathrm{~kg} / \mathrm{ha}$ of product $(4.5 \mathrm{~kg} / \mathrm{ha}$ of metallic $\mathrm{Cu}$ ). The application dates were: one spray, 5 May; two sprays, 24 April and 26 May; three sprays, 14 April, 5 May, and 26 May; and four sprays, 8 April, 24 April, 15 May, and 2 June.

In October or November of each year when the fruit had reached maturity, 50 or 100 fruit per tree were arbitrarily selected and evaluated. Fruit were rated on a scale of 0 to 5 , where $0=$ no melanose; $1=$ mild melanose, suitable for fresh market; $2=$ moderate speck melanose, suitable only for processing; $3=$ severe speck melanose; 4 = moderate tear-stain or mudcake melanose; and $5=$ severe tear-stain or mudcake melanose. The percentage of fruit acceptable for fresh market fruit (i.e., fruit rated as 0 or 1) was calculated for each treatvariance and means separated using the Waller-Duncan k-ratio $t$ test, $P \leq 0.05$.

Copper residue analysis. Total residues of metallic copper per fruit and per $\mathrm{cm}^{2}$ of fruit surface were determined at various dates after one Kocide 2000 application in 1996, one Champ Formula II Flowable application in 1996, and one Kocide 2000 application in 1997. Twenty-five fruit were selected arbitrarily from each replicate plot. Each fruit sample was placed in a plastic bag and washed with $500 \mathrm{ml}$ ment. Data were subjected to analysis of

deionized water. The wash solution was passed through a filter paper and the filtrate was used for analysis of copper residues. The filter paper was also ashed at $500^{\circ} \mathrm{C}$ in a muffle furnace for $15 \mathrm{~h}$ and the ash dissolved in $50 \mathrm{ml}$ of 5\% HCL. Each fruit was washed a second time with 500 $\mathrm{ml}$ 5\% HCL and filtered as above. Copper residues in the filter paper and filtrate were determined as above. The total copper in all samples was determined by the University of Florida Cooperative Extension Service Soil Testing Laboratory using an inductively coupled argon plasma spectrophotometer.

The surface area of the fruit was determined by first ascertaining the fruit volume by noting the change in volume after submerging the fruit in water. Average fruit surface area was calculated assuming that fruit was spherical using the formula: $A=$ $(4 \pi)^{1 / 3}(3 V)^{2 / 3}$, where $A=$ the average fruit surface area and $V=$ the average volume. Copper residues were calculated on the basis of total per fruit and amount per unit area of surface.

Economic analysis. The net return per hectare was determined for zero to four spray applications of Kocide in 1995, 1996, and 1997. The price used for calculations was the average price for fresh market and processing fruit from the 199394, 1994-95, and the 1995-96 seasons (6). The application costs used were the average price for custom application (8) which should include not only the labor and fuel cost, but also capital expenditures and overhead.

\section{RESULTS}

Effect of application frequency on melanose severity. In 1995, melanose infection was severe due to high rainfall in late May and June. Major infection periods occurred from 19 to 20 May (128 mm rain), from 31 May to 5 June $(233 \mathrm{~mm})$,

Table 1. Effect of the number of applications of two copper fungicides on the severity of melanose and the percentage of marketable fruit of Marsh grapefruit

\begin{tabular}{|c|c|c|c|c|c|c|c|}
\hline \multirow[b]{2}{*}{ Product $^{x}$} & \multirow[b]{2}{*}{ No. of applications } & \multicolumn{3}{|c|}{ Severity rating $(0-5)^{\mathrm{w}}$} & \multicolumn{3}{|c|}{ Marketable fresh (\%) } \\
\hline & & 1995 & 1996 & 1997 & 1995 & 1996 & 1997 \\
\hline \multirow{5}{*}{ Kocide } & 0 & $2.5 \mathrm{a}^{\mathrm{y}}$ & $1.6 \mathrm{a}$ & $3.0 \mathrm{a}$ & $11 \mathrm{e}$ & $51 \mathrm{~b}$ & $1 \mathrm{c}$ \\
\hline & 1 & $1.4 \mathrm{~b}$ & $1.0 \mathrm{~b}$ & $1.8 \mathrm{~b}$ & $61 \mathrm{~b}$ & $90 \mathrm{a}$ & $40 \mathrm{~b}$ \\
\hline & 2 & $1.5 \mathrm{~b}$ & $1.0 \mathrm{~b}$ & $1.9 \mathrm{~b}$ & $60 \mathrm{~b}$ & $87 \mathrm{a}$ & $35 \mathrm{~b}$ \\
\hline & 3 & $1.4 \mathrm{~b}$ & $1.1 \mathrm{~b}$ & $1.5 \mathrm{bc}$ & $61 \mathrm{~b}$ & $83 \mathrm{a}$ & $57 \mathrm{ab}$ \\
\hline & 4 & $1.1 \mathrm{c}$ & $0.9 \mathrm{~b}$ & $1.2 \mathrm{c}$ & $79 a$ & $92 \mathrm{a}$ & $72 \mathrm{a}$ \\
\hline \multicolumn{8}{|l|}{ Champ } \\
\hline \multirow[t]{4}{*}{ Formula II } & 1 & $1.7 \mathrm{~b}$ & $1.0 \mathrm{~b}$ & $\ldots^{\mathrm{z}}$ & $48 \mathrm{~cd}$ & $88 \mathrm{a}$ & $\ldots$ \\
\hline & 2 & $1.7 \mathrm{~b}$ & $1.1 \mathrm{~b}$ & $\ldots$ & $47 \mathrm{~cd}$ & $85 \mathrm{a}$ & $\ldots$ \\
\hline & 3 & $1.8 \mathrm{~b}$ & $1.0 \mathrm{~b}$ & $\ldots$ & $43 \mathrm{~d}$ & $87 \mathrm{a}$ & $\ldots$ \\
\hline & 4 & $1.6 \mathrm{bc}$ & $1.0 \mathrm{~b}$ & $\ldots$ & $54 \mathrm{bc}$ & $84 \mathrm{a}$ & $\ldots$ \\
\hline
\end{tabular}

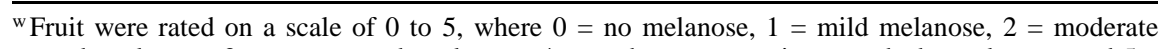
speck melanose, $3=$ severe speck melanose, $4=$ moderate tear-stain or mudcake melanose, and $5=$ severe tear-stain or mudcake melanose.

x Kocide applied as Kocide DF (40\% metallic copper) in 1995 at $9.1 \mathrm{~kg} / \mathrm{ha}$ of metallic copper using the same amount of copper per season regardless of the number of applications; Kocide 2000 (35\% metallic copper) was used at $9.1 \mathrm{~kg} / \mathrm{ha}$ of metallic copper in 1996 and $4.5 \mathrm{~kg} / \mathrm{ha}$ in 1997. Champ Formula II was used at $4.5 \mathrm{~kg} / \mathrm{ha}$ of metallic copper in 1995 and 1996.

${ }^{\mathrm{y}}$ Mean separation by the Waller-Duncan k-ratio $t$ test, $P \leq 0.05$.

$\mathrm{z} \ldots=$ not tested. and from 22 to 26 June $(208 \mathrm{~mm})$. Additional infection occurred on 25 April (13 $\mathrm{mm}), 28$ April $(33 \mathrm{~mm})$, and 10 June (30 $\mathrm{mm})$. Only $11 \%$ of the fruit were marketable fresh in the unsprayed control (Table 1). One to three sprays of Kocide decreased melanose severity ratings and greatly increased the percentage of the fruit marketable as fresh. Four spray applications provided the best melanose control. A similar pattern was observed with Champ, but it was less effective since it was applied at half the rate of metallic copper.

In 1996, melanose infection was less severe, with major infection periods on 11 to 15 April (58 mm), 26 to 28 April (70 mm), 31 May to 1 June $(35 \mathrm{~mm})$, and 9 to 15 June $(133 \mathrm{~mm})$. Other minor infection periods occurred on 23 April (11 mm), 12 May (39 mm), 19 May (9 mm), and 5 to 6 June $(17 \mathrm{~mm})$. Over $50 \%$ of the fruit were marketable as fresh in the unsprayed control. Even a single application of Champ at only $4.5 \mathrm{~kg} / \mathrm{ha}$ of metallic copper significantly reduced severity ratings and increased the percentage of the marketable fruit. More frequent applications of either product did not improve control.

In 1997, melanose infection was again very severe. Major infection periods occurred from 10 to 11 June $(103 \mathrm{~mm})$ and 18 to 22 June $(118 \mathrm{~mm})$. Minor infection periods occurred on 16 April (6 mm), 30 April to 1 May (26 mm), 21 to 23 May (19 $\mathrm{mm}), 29$ to 31 May (28 mm), 15 to 16 June $(13 \mathrm{~mm})$, and 25 to 26 June (38 mm). Only $1 \%$ of the fruit were marketable as fresh in the unsprayed control. One or two sprays of Kocide 2000 provided some control, but three or four applications significantly improved melanose control.

Copper residues. In 1996, fruit was relatively small when the initial samples were collected from the Kocide and Champ treatments (Table 2). Fruit surface area increased more than fourfold from the first to the last sampling date. Total copper residue of Kocide per fruit at the last sampling was half of the initial residue, whereas the copper residue per $\mathrm{cm}^{2}$ was only one-eighth of the initial residue. On fruit sprayed with Champ, copper residue per fruit did not decline significantly during the sampling period, but the amount per unit area of surface declined to oneeighth of the initial residue.

In 1997, bloom occurred earlier and fruit were larger when first sampled (Table 2). Copper deposits were lower initially in 1997 than in 1996. Fruit surface area increased less than twofold from initial to final sampling. Total copper residue per fruit and the residue per unit area declined at about the same rate.

Economic analysis. In 1995 and 1997, the four-application schedule provided the greatest net return (Table 3). In 1996, with the lowest melanose severity, the one- to four-application schedules provided about the same net return. Costs for more fre- 
quent applications were low compared to the difference in returns between fresh and processed fruit.

\section{DISCUSSION}

Split applications of copper fungicides improved the control of melanose in 2 of the 3 years studied. Copper fungicides for control of melanose must be applied as preventive sprays. Application of four sprays at about 3-week intervals provided the best control and was clearly economically advantageous. This may seem intuitively obvious, but, in previous studies with single applications of copper fungicides (10), melanose control was linearly related to the amount of metallic copper applied. Even at rates as high as $9.1 \mathrm{~kg} / \mathrm{ha}$ of metallic copper, there was no indication that an asymptote in disease control had been reached.

In years when disease severity is low, additional application costs would be incurred in the four-spray program. However, there is no way to predict severity in advance and additional costs in those years would be more than offset by the gains achieved when the disease severity is high.

Applications of four sprays of $4.5 \mathrm{~kg} / \mathrm{ha}$ of copper usually provided satisfactory control. Rates of $4.5 \mathrm{~kg} / \mathrm{ha}$ of metallic copper per season, even with the high quality copper products used in these tests, may be insufficient to produce fruit with high exterior quality in all years. Probably 6 to 9 $\mathrm{kg} / \mathrm{ha}$ of copper per season divided among four applications would be needed to assure superior control. This is still far less than the rates of copper used previously and will reduce accumulation of copper in soils $(3,4)$ and the risk of spray burn due to copper $(2,5,9)$.

Copper fungicides have a long residual period of activity against conidia of Phomopsis citri, but are not readily redistributed to newly formed tissue (11). In the current study, we found that total copper residues per fruit declined slowly compared to the amount of copper per unit of surface area, especially when fruit size was increasing rapidly. When fruit was growing more slowly, the rate of decline of copper deposits per fruit was similar to the rate of decline per unit of surface area. Thus, it appears that loss of effectiveness against melanose on rapidly growing young fruit is more attributable to fruit growth than to loss of deposits due to rainfall or environmental factors. On larger, more slowly growing fruit, both factors may be equally important. Other studies investigating the effects of spray volumes on copper residues tend to support these conclusions (2).

Utilization of the four-spray program permits application throughout the period that fruit is susceptible to melanose. That program provides more complete coverage of rapidly growing fruit and replaces deposits lost by weathering. Thus, more effective control is attained without increasing the amount of fungicide applied. Recommendations to growers have been adjusted to reflect these results (7).

\section{ACKNOWLEDGMENTS}

We thank W. Vanden Bosch for excellent technical assistance.

Table 2. Effect of fruit growth and rainfall on the copper residues remaining on fruit after application of fungicides

\begin{tabular}{|c|c|c|c|c|c|}
\hline \multirow[b]{2}{*}{ Product } & \multirow[b]{2}{*}{ Sample date } & \multirow[b]{2}{*}{ Rainfall $(\mathbf{m m})^{t}$} & \multirow[b]{2}{*}{ Fruit surface area $\left(\mathrm{cm}^{2}\right)^{u}$} & \multicolumn{2}{|c|}{ Metallic $\mathrm{Cu}$ residue } \\
\hline & & & & mg/fruit ${ }^{v}$ & $\mu \mathrm{g} / \mathrm{cm}^{2}$ fruit surface ${ }^{w}$ \\
\hline \multirow[t]{3}{*}{ Kocide $2000^{x}$} & 1 May 96 & 0 & $138 \pm 19$ & $1.93 \pm 0.45(100)$ & $13.9 \pm 1.9(100)$ \\
\hline & 15 May & 39 & $382 \pm 72$ & $1.48 \pm 1.40$ & $4.4 \pm 4.2$ \\
\hline & 29 May & 48 & $597 \pm 105$ & $1.03 \pm 0.35$ & $1.7 \pm 0.4$ \\
\hline \multirow[t]{3}{*}{ Champ Formula II $^{y}$} & 1 May 96 & 0 & $78 \pm 33$ & $0.99 \pm 0.53$ & $13.3 \pm 6.0(100)$ \\
\hline & 15 May & 39 & $373 \pm 65$ & $0.60 \pm 0.82$ & $1.6 \pm 2.1$ \\
\hline & 29 May & 48 & $631 \pm 118$ & $1.04 \pm 0.37(105)$ & $1.7 \pm 0.6$ \\
\hline \multirow[t]{4}{*}{ Kocide $2000^{z}$} & 6 May & 0 & $308 \pm 103$ & $1.83 \pm 1.03(100)$ & $5.6 \pm 1.4(100)$ \\
\hline & 20 May & 0 & $374 \pm 29$ & $0.55 \pm 0.26$ & $1.4 \pm 0.7$ \\
\hline & 3 June & 47 & $552 \pm 36$ & $0.36 \pm 0.21$ & $0.6 \pm 0.4$ \\
\hline & 18 June & 163 & $495 \pm 27$ & $0.13 \pm 0.08$ & $0.3 \pm 0.2$ \\
\hline
\end{tabular}

$\mathrm{t}$ Total rainfall since the application of fungicide.

" Fruit surface area \pm standard deviation.

$\checkmark$ Total copper residues per fruit in $\mathrm{mg} \pm$ standard deviation. Numbers in parentheses are the percentages of initial residue remaining.

${ }^{\text {w }}$ Copper residue per $\mathrm{cm}^{2}$ of fruit surface \pm standard deviation. Number in parentheses are the percentages of the initial residue.

x Applied on 30 April 96 at $9.1 \mathrm{~kg}$ metallic copper/ha.

y Applied on 30 April 96 at $4.5 \mathrm{~kg}$ metallic copper/ha.

z Applied 5 May 97 at $4.5 \mathrm{~kg}$ metallic copper/ha.

Table 3. Estimated returns per hectare of Marsh grapefruit when zero to four applications of Kocide were made from 1995 to 1997

\begin{tabular}{|c|c|c|c|c|c|c|c|}
\hline \multirow[b]{2}{*}{ Year } & \multirow[b]{2}{*}{ No. of applications } & \multicolumn{2}{|c|}{ Fresh $^{y}$} & \multicolumn{2}{|c|}{ Processing } & \multirow[b]{2}{*}{ Application $\cos ^{\mathrm{z}}$} & \multirow[b]{2}{*}{ Net return (\$) } \\
\hline & & Tons & Return (\$) & Tons & Return (\$) & & \\
\hline \multirow[t]{5}{*}{1995} & 0 & 4.6 & 575 & 37.4 & 486 & 0 & 1,061 \\
\hline & 1 & 25.6 & 3,203 & 16.4 & 213 & -63 & 3,353 \\
\hline & 2 & 25.2 & 3,150 & 16.8 & 218 & -125 & 3,291 \\
\hline & 3 & 25.6 & 3,203 & 16.4 & 213 & -188 & 3,228 \\
\hline & 4 & 33.2 & 4,148 & 8.8 & 115 & -250 & 4,013 \\
\hline \multirow[t]{5}{*}{1996} & 0 & 21.4 & 2,678 & 20.6 & 268 & 0 & 2,946 \\
\hline & 1 & 37.8 & 4,725 & 4.2 & 55 & -63 & 4,717 \\
\hline & 2 & 36.5 & 4,568 & 5.5 & 71 & -125 & 4,514 \\
\hline & 3 & 34.9 & 4,358 & 7.1 & 93 & -188 & 4,263 \\
\hline & 4 & 38.6 & 4,830 & 3.4 & 44 & -250 & 4,624 \\
\hline \multirow[t]{5}{*}{1997} & 0 & 0.4 & 53 & 41.6 & 541 & 0 & 594 \\
\hline & 1 & 16.8 & 2,100 & 25.2 & 328 & -63 & 2,365 \\
\hline & 2 & 14.7 & 1,838 & 27.3 & 355 & -125 & 2,068 \\
\hline & 3 & 23.9 & 2,993 & 18.1 & 235 & -188 & 3,040 \\
\hline & 4 & 30.2 & 3,780 & 7.6 & 98 & -250 & 3,628 \\
\hline
\end{tabular}

${ }^{\mathrm{y}}$ Based on the percent fruit marketable as fresh from each treatment in Table 1. Value of fruit was the average for 1993 to 1996 with fresh fruit price at $\$ 125 /$ metric ton and processing fruit at $\$ 13 /$ metric ton (6).

${ }^{\text {z }}$ Custom application cost estimated at \$63/ha (8). 
LITERATURE CITED

1. Albrigo, L. G., and Grosser, J. W. 1996. Methods of evaluation of spray chemical phytotoxicity to citrus. Proc. Fla. State Hortic. Soc. 109:52-57.

2. Albrigo, L. G., Timmer, L. W., Townsend, K., and Beck, H. W. Copper fungicides-residues for disease control and potential for spray burn. Proc. Fla. State Hortic. Soc. 110:67-70.

3. Alva, A. K., and Graham, J. H. 1991. The role of copper in citriculture. Adv. Agron. 1:145170.

4. Alva, A. K., Graham, J. H., and Tucker, D. P. H. 1993. Role of calcium in the amelioration of copper phytotoxicity for citrus. Soil Sci. 155:211-218.

5. Brodrick, H. T. 1970. Accentuation of blemish marks by copper fungicide sprays. S. Afr. Citrus J. 441:27-29, 31.

6. Florida Agricultural Statistics Service. 1997. Citrus Summary, 1995-96. U. S. Dep. Agric. Agric. Mark. Serv. Natl. Agric. Statistics Serv.

7. Knapp, J. L., ed. 1998. 1998 Florida Citrus Pest Management Guide. Publ. No. SP-43. Univ. Fla. Coop. Ext. Serv., Inst. Food Agric. Sci. University of Florida, Gainesville.

8. Muraro, R. P., and Hebb, J. W. 1997. Budgeting Costs and Returns for Indian River Cit- rus Production, 1996-97. Univ. Fla. Inst. Food Agric. Sci. Econ. Info. Rep. 97:7.

9. Schutte, G. C., Beeton, K. V., and Kotze, J. M. 1997. Rind stippling on Valencia oranges by copper fungicides used for control of citrus black spot in South Africa. Plant Dis. 81:851854.

10. Timmer, L. W., and Zitko, S. E. 1996 Evaluation of copper fungicides and rates of metallic copper for control of melanose on grapefruit in Florida. Plant Dis. 80:166-169.

11. Whiteside, J. O. 1977. Sites of action of fungicides in the control of citrus melanose. Phytopathology 67:1067-1072. 